Marquette University

e-Publications@Marquette

Physics Faculty Research and Publications

Physics, Department of

$9-1-2008$

\title{
Spectroscopic Studies on Arabidopsis ETHE1, a Glyoxalase II-like Protein
}

\author{
Meghan M. Holdorf \\ Miami University - Oxford \\ Brian Bennett \\ Marquette University, brian.bennett@marquette.edu \\ Michael W. Crowder \\ Miami University - Oxford \\ Christopher A. Makaroff \\ Miami University - Oxford
}

Accepted version. Journal of Inorganic Biochemistry, Vol. 102, No. 9 (September 2008): 1825-1830. DOI. (C) 2008 Elsevier. Used with permission.

NOTICE: this is the author's version of a work that was accepted for publication in Journal of Inorganic Biochemistry. Changes resulting from the publishing process, such as peer review, editing, corrections, structural formatting, and other quality control mechanisms may not be reflected in this document. Changes may have been made to this work since it was submitted for publication. A definitive version was subsequently published in Journal of Inorganic Biochemistry, VOL 102, ISSUE 9, September 2008, DOI.

Brian Bennett was affiliated with Medical College of Wisconsin at the time of publication. 


\title{
Spectroscopic studies on Arabidopsis ETHE1, a glyoxalase II- like protein
}

\author{
Meghan M. Holdorf \\ Department of Chemistry and Biochemistry, Miami University \\ Oxford, $\mathrm{OH}$ \\ Brian Bennett \\ National Biomedical EPR center, Department of Biophysics, \\ Medical College of Wisconsin \\ Milwaukee, WI \\ Michael W. Crowder \\ Department of Chemistry and Biochemistry, Miami University \\ Oxford, $\mathrm{OH}$ \\ Christopher A. Makaroff* \\ Department of Chemistry and Biochemistry, Miami University \\ Oxford, $\mathrm{OH}$
}

\begin{abstract}
ETHE1 (ethylmalonic encephalopathy protein 1 ) is a $\beta$-lactamase fold-containing protein that is essential for the survival of a range of organisms. In spite of the apparent importance of this enzyme, very little is known about its function or biochemical properties. In this study Arabidopsis ETHE1 was over-expressed and purified and shown to bind tightly to $1.2 \pm$
\end{abstract}


0.2 equivalents of iron. ${ }^{1} \mathrm{H}$ NMR and EPR studies demonstrate that the predominant oxidation state of Fe in ETHE1 is Fe(II), and NMR studies confirm that two histidines are bound to Fe(II). EPR studies show that there is no antiferromagnetically-coupled Fe(III)Fe(II) center in ETHE1. Gel filtration studies reveal that ETHE1 is a dimer in solution, which is consistent with previous crystallographic studies. Although very similar in terms of amino acid sequence to glyoxalase II, ETHE1 exhibits no thioester hydrolase activity, and activity screening assays reveal that ETHE1 exhibits low level esterase activity. Taken together, ETHE1 is a novel, mononuclear Fe(II)-containing member of the $\beta$-lactamase fold superfamily.

Keywords: $\beta$-lactamase fold, Fe(II), ETHE1, NMR spectroscopy, EPR spectroscopy

\section{Introduction}

Mutations in the ethylmalonic encephalopathy protein 1 (ETHE1) are responsible for the complex human disease ethylmalonic encephalopathy (EE) $[\underline{1}, \underline{2}]$. The symptoms of EE are well characterized, yet the underlying physiological cause of the disease remains unknown [1]. Symptoms associated with EE include chronic diarrhea, a delay in neural development, symmetric brain lesions, relapsing petechiae, lactic academia, and acrocyanosis of the hands and feet, all of which lead to death within the first few years of life [3] . Biochemical alterations associated with of EE include elevated levels of C4 and C5 plasma acylcarnitines and elevated levels of ethylmalonic acid (EMA). Based on these biochemical alterations, it has been suggested that ETHE1 may be involved in the $\beta$-oxidation of shortchain acyl-CoAs [1]].

ETHE1-like enzymes are found in most organisms including archaebacteria, insects, plants, and animals, suggesting that ETHE1 serves a fundamental biochemical role in nature; however, the exact biochemical role of ETHE1 is currently unknown. ETHE1 is most similar to the glyoxalase II family of proteins that catalyze the second step of the glyoxalase pathway. The glyoxalase pathway, which consists of glyoxalase I (lactoylglutathione lyase) (GLX1) and glyoxalase II (hydroxacylglutathione hydrolase) (GLX2), is thought to be involved in the detoxification of 2-oxoaldehydes, toxic by-products of carbohydrate and lipid metabolism [4]. The primary physiological substrate appears to be methylglyoxal (2-oxopropanal), a reactive aoxoaldehyde [4].

Journal of Inorganic Biochemistry, Vol. 102, No. 9 (September 2008): pg. 1825-1830. DOI. This article is (C Elsevier and permission has been granted for this version to appear in e-Publications@Marquette. Elsevier does not grant permission for this article to be further copied/distributed or hosted elsewhere without the express permission from Elsevier. 
GLX2 enzymes belong to the metallo- $\beta$-lactamase fold family of proteins, which are typically dinuclear metallohydrolases. The metallo$\beta$-lactamases typically bind two equivalents of $\mathrm{Zn}(\mathrm{II})$ and hydrolyze $\beta$ lactams $[\underline{5}, \underline{6}]$. GLX2 enzymes, which hydrolyze SLG, contain dinuclear metal centers that can bind $\mathrm{Zn}, \mathrm{Fe}$, and $\mathrm{Mn}$ [ $\underline{7}$ ]. Additional protein families containing the $\beta$-lactamase fold include the rubredoxin:oxygen oxidoreductase (ROO) and ZiPD families, which have been shown to bind divalent Fe and $\mathrm{Zn}(\mathrm{II})$, respectively $[\underline{8}, \underline{9}]$. Therefore, the $\beta$ lactamase fold can accommodate several different metals and is present in enzymes that can catalyze a wide range of reactions.

Arabidopsis ETHE1 is 54\% identical to human ETHE1. Crystal structure comparisons between Arabidopsis ETHE1 [10] and Arabidopsis GLX2-5, a mitochondrial GLX2 enzyme [11], revealed that while the proteins show only $13 \%$ sequence identity, ETHE1 is structurally very similar to GLX2 [12]. ETHE1 and GLX2 enzymes contain a very similar metal binding domain and the $\beta$-lactamase fold consisting of two central mixed $\beta$-sheets surrounded on both sides by helices $[12,13]$. Interestingly, even though ETHE1 and GLX2 enzymes exhibit extensive similarity in their metal binding regions, the ETHE1 crystal structure showed it only bound a single metal atom [12]. In fact, the crystal structure was best refined to a metal occupancy of 0.5 [12]. However, the metal content of purified ETHE1 was reported to be 2 equivalents of metal per equivalent of protein, raising the question of the actual metal content of this enzyme.

We have over-expressed, purified, and biochemically- and spectroscopically-characterized Arabidopsis ETHE1 to further investigate structural and biochemical properties of ETHE1 enzymes and to better understand the functional role of ETHE1. The results of these studies show that Arabidopsis ETHE1 is homodimeric in solution, exhibits low-level esterase activity, and specifically binds a single $\mathrm{Fe}(\mathrm{II})$ atom in the active site.

Journal of Inorganic Biochemistry, Vol. 102, No. 9 (September 2008): pg. 1825-1830. DOI. This article is (c) Elsevier and permission has been granted for this version to appear in e-Publications@Marquette. Elsevier does not grant permission for this article to be further copied/distributed or hosted elsewhere without the express permission from Elsevier. 
NOT THE PUBLISHED VERSION; this is the author's final, peer-reviewed manuscript. The published version may be accessed by following the link in the citation at the bottom of the page.

\section{Materials and Methods}

\section{Over-expression and purification of A.t. ETHE1}

The Arabidopsis ETHE1 cDNA was obtained from Arabidopsis bud RNA and cloned into pET24b as Nde1 and XhoI fragments following reverse transcription and $P C R$ amplification using the primers GLX2-3 (TCTTCTCATATGAAGCTTCTCTTTCGTCAAC) and a 3'poly (A) anchor primer. During cloning the $\mathrm{N}$-terminal leader peptide was removed for high-level expression of ETHE1 in E. coli, resulting in the amino terminal methionine, which corresponds to amino acid 50 of the predicted protein sequence. This is the same form of the protein that was used for crystal structure determination [12]. After verification by DNA sequencing, pET24b-ETHE1 was transformed into BL21-Codon Plus (DE3)-RIL cells and used for protein over-expression and purification as previously described [ ]]. Protein purity was determined by SDS-polyacrylamide gel electrophoresis, and protein concentrations were determined by using an extinction coefficient $\left(\varepsilon_{280 \mathrm{~nm}}\right)$ of 7,240 $\mathrm{M}^{-1} \mathrm{~cm}^{-1}$, which was determined using amino acid analyses.

\section{Metal analyses}

Metal analyses were performed on the purified enzyme using a Varian-Liberty 150 inductively coupled plasma spectrometer with atomic emission spectroscopy detection (ICP-AES) as described previously [13]. The purified protein was diluted to $10 \mu \mathrm{M}$ in $50 \mathrm{mM}$ TRIS, $\mathrm{pH} 7.2$, and analyzed for the presence of zinc, manganese, iron, and copper. The data presented in this report represent the average of at least three preparations for each metal addition experiment.

\section{Native molecular weight determination}

The native molecular weight of ETHE1 was determined by utilizing a Sephacryl S200 column in 10 mM MOPS, pH 7.2, containing $0.15 \mathrm{M} \mathrm{NaCl}$. ETHE1 (1 mg), purified as described above, was mixed with $1 \mathrm{mg}$ of each of the protein standards: Blue Dextran, bovine serum albumin, ovalbumin, aldolase, and ribonuclease A. One milliliter fractions were collected with a flow rate of $0.5 \mathrm{ml} / \mathrm{min}$, and samples

Journal of Inorganic Biochemistry, Vol. 102, No. 9 (September 2008): pg. 1825-1830. DOI. This article is @ Elsevier and permission has been granted for this version to appear in e-Publications@Marquette. Elsevier does not grant permission for this article to be further copied/distributed or hosted elsewhere without the express permission from Elsevier. 
containing protein were identified by monitoring $A_{280}$ and by SDS-PAGE gel analysis.

\section{Substrate analysis}

Enzymatic assays were conducted at $25^{\circ} \mathrm{C}$ in $10 \mathrm{mM}$ MOPS, $\mathrm{pH}$ 7.2, on a Cary IE UV-Vis spectrophotometer. A series of thioesters of glutathione were synthesized as previously described [14], and all other substrates were purchased commercially. The hydrolysis of S- $D$ lactoylglutathione (Sigma), S-D-acetylglutathione, S-Dacetoacetylglutathione, S-D-formylglutathione, S- $D$ glyocosylgutathione or S-D-pyruvylglutathione was monitored at 240 $\mathrm{nm}$. S-D-mandeloylglutathione hydrolysis was monitored at $263 \mathrm{~nm}$ [14]. Hydrolysis of $p$-nitrophenyl phosphate (Sigma), p-nitrophenyl sulfate (Sigma), and $p$-nitrophenyl acetate (Sigma) was monitored at $400 \mathrm{~nm}$ [15-17]. The hydrolysis of $L$-alanine- $p$-nitroanilide (Sigma) was measured at $404 \mathrm{~nm}$ [16]. Ala-ala-ala-p-nitroanilide (Sigma) and $y$-L-Glu- $p$-nitroanalide (Sigma) hydrolysis was monitored at $410 \mathrm{~nm}$. Hydrolysis of benzoylglycyl-L-phenylalanine was monitored at $254 \mathrm{~nm}$ [18]. Nitrocefin (Becton-Dickinson) hydrolysis was monitored at 485 $\mathrm{nm}$ [19]. Methylglyoxal was assayed colorimetrically by using the 2,3dinitrophenylhydrazine-alkali reaction [20]. Assays were performed for 5 min using $80 \mu \mathrm{M}$ substrate and varying concentrations of pure enzyme both as-isolated and after loading with excess iron.

Additional substrate screening was performed using the Micronaut-Taxa Profile E (Merlin $\mathrm{GmbH}$ ) microtiter plate []]. Each well was filled with $25 \mu \mathrm{l}$ of $40 \mu \mathrm{M}$ ETHE1, and reactions prepared according to manufacturer's directions. A negative control was performed using MOPS, $\mathrm{pH} 7.2$, to rule out non-specific reactions. The reactions were monitored visually for 24 hours at $37^{\circ} \mathrm{C}$, and positive reactions were recorded. Each reaction was performed in duplicate using enzyme loaded with iron.

\section{EPR Spectroscopy}

EPR spectra were obtained at $9.63 \mathrm{GHz}$ and $10 \mathrm{~K}$ using a Bruker EleXsys E580 spectrometer equipped with an ER4116DM cavity, and an Oxford ESR900 liquid helium flow cryostat and ITC503 temperature

Journal of Inorganic Biochemistry, Vol. 102, No. 9 (September 2008): pg. 1825-1830. DOI. This article is (C Elsevier and permission has been granted for this version to appear in e-Publications@Marquette. Elsevier does not grant permission for this article to be further copied/distributed or hosted elsewhere without the express permission from Elsevier. 
NOT THE PUBLISHED VERSION; this is the author's final, peer-reviewed manuscript. The published version may be accessed by following the link in the citation at the bottom of the page.

controller. Acquisition parameters included $12 \mathrm{G}(1.2 \mathrm{mT})$ field modulation at $100 \mathrm{kHz}$. Samples contained $1.6 \mathrm{mM}$ ETHE1 protein in 50 mM TRIS, $\mathrm{pH} 7.2$.

\section{${ }^{1}$ H NMR Spectroscopy}

NMR spectra were collected on a Bruker Avance 500 spectrometer operating at $500.13 \mathrm{MHz}, 298 \mathrm{~K}$, and a magnetic field of 11.7 tesla, recycle delay (AQ), $41 \mathrm{~ms}$, and sweep width, 400 ppm. Concentrated samples of ETHE1 ( $1.4 \mathrm{mM})$ contained $10 \% \mathrm{D}_{2} \mathrm{O}$ for locking or $90 \% \mathrm{D}_{2} \mathrm{O}$ for monitoring of solvent-exchangeable peaks. Protein chemical shifts were calibrated by assigning the $\mathrm{H}_{2} \mathrm{O}$ signal a value of $4.70 \mathrm{ppm}$, and a modified presaturation pulse sequence (zgpr) was used to suppress the proton signals that originated from the water molecules.

\section{Results}

\section{Over-expression, purification, and characterization of Arabidopsis ETHE1}

Based on publicly-available localization prediction programs (pSORT II, Mitoprot), recombinant ETHE1 was cloned into the pET24b expression vector after removing the predicted 50 amino acid $\mathrm{N}$-terminal leader sequence, which generated an N-terminus of MKLLFRQ (Figure 1). This plasmid was transformed into E. coli BL21(RIL) Rosetta cells, and ETHE1 was over-expressed as described in Material and Methods. ETHE1 was purified using FPLC Q-Sepharose chromatography, eluting from the column at $\sim 125 \mathrm{mM} \mathrm{NaCl}$. Purified ETHE1 protein was obtained in high yield ( $\sim 40-60 \mathrm{mg}$ of protein/L) and was $>95 \%$ pure (data not shown).

Journal of Inorganic Biochemistry, Vol. 102, No. 9 (September 2008): pg. 1825-1830. DOI. This article is (c) Elsevier and permission has been granted for this version to appear in e-Publications@Marquette. Elsevier does not grant permission for this article to be further copied/distributed or hosted elsewhere without the express permission from Elsevier. 
NOT THE PUBLISHED VERSION; this is the author's final, peer-reviewed manuscript. The published version may be accessed by following the link in the citation at the bottom of the page.

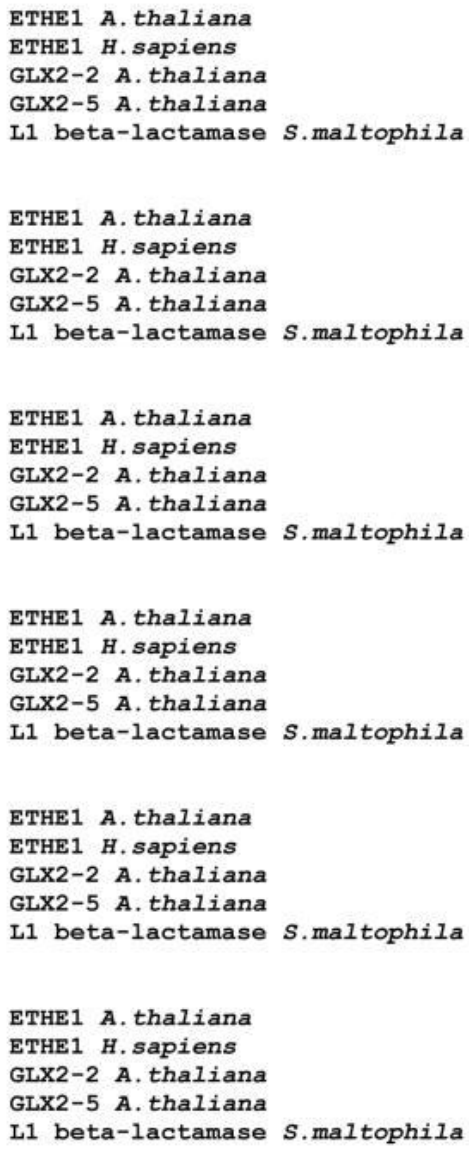

MVMTHFSRLRQLLLIQPKFLSSERPRLRSPPPTFLRSVM 39 MAEAVILRVAR 10 MQTISKASSATSFFRCSRLSSQPPCVREINIRKSLVCRVMKLVSSPLRTLR 50

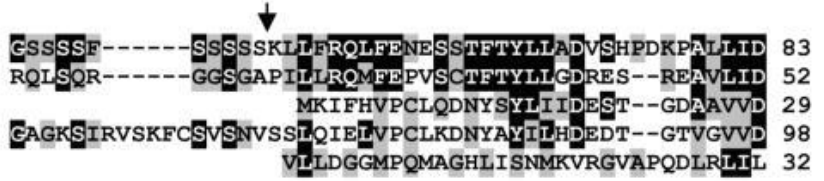

$\Delta \mathbf{\Delta} \mathbf{\Delta}$

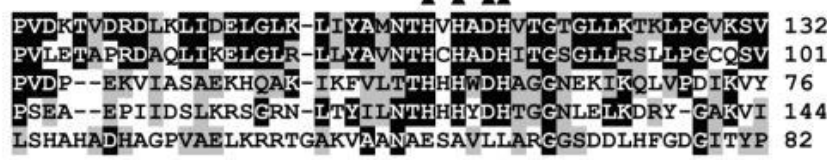

ISKASG---SKADLFLEPGDKVSIED-IYLEVRATPGHTAGCVTYVTGEG 178 ISRISG---AQADLHIEDGDSIRFGR-FALETRASPGHTPGCVTFVLNDH 147 GGSLDK--VKGCTDAVDNGDKLTLGQDINILALHTPCHTKCHISYYVNGK 124 GSAMDKDRI PGIDMALKD GDKWMFAG-HEVHVMDTPGHTKGHISLYFPG- 192 PASADR---.--IVMDGEMITVGG-IAFTAHFMPGHTPGSTAWTWTDT 123

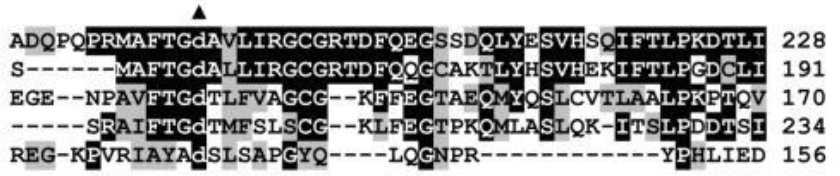
REG-KPVRIAYAdSLSAPGYQ---LQGNPR-------YPHLIED 156

$\Delta$

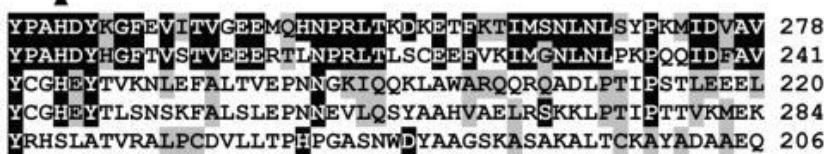

\begin{tabular}{ll}
\hline PANMVCGIDVPSQAN & 294 \\
PANMRCGVQTPTA & 254 \\
ETNPFMRVDKPEIQEKLG---CKSPIDTMREVRNKKDQWRG & 258 \\
ACNPFLRSSNTDIRRALRI PEAADEAEALGI IRKAKDDF & 323 \\
KFDAOLAKETAGAR & 220
\end{tabular}

\section{Figure 1: Sequence Alignment of ETHE1 and select metallo- $\beta$-lactamase fold} proteins

Protein sequences were aligned using CLUSTAL W (1.83). Identical residues are highlighted with black and similar residues with gray highlight. Conserved metal binding ligands are indicated by closed triangles. Residues labeled with an asterisk are mutated in patients with EE. Predicted $\mathrm{N}$-terminal processing site is indicated by an arrow.

\section{ETHE1 is a dimer in solution}

In contrast to the GLX2 enzymes, which exist as monomers in solution $[\underline{21}, \underline{22}]$, the crystal structure of Arabidopsis ETHE1 suggested that it has a dimeric quaternary structure [12]. Gel filtration studies were performed on the recombinant ETHE1 enzyme to test this hypothesis. ETHE1 eluted from a Sephacryl S200 column between standard proteins adolase (158 kDa) and ovalbumin (44 kDa), 
resulting in a calculated molecular weight of $58.3 \mathrm{kDa}$, which is roughly twice the recombinant monomeric weight of $26.8 \mathrm{kDa}$ (Figure 2). Therefore, Arabidopsis ETHE1 exists as a dimer in solution.

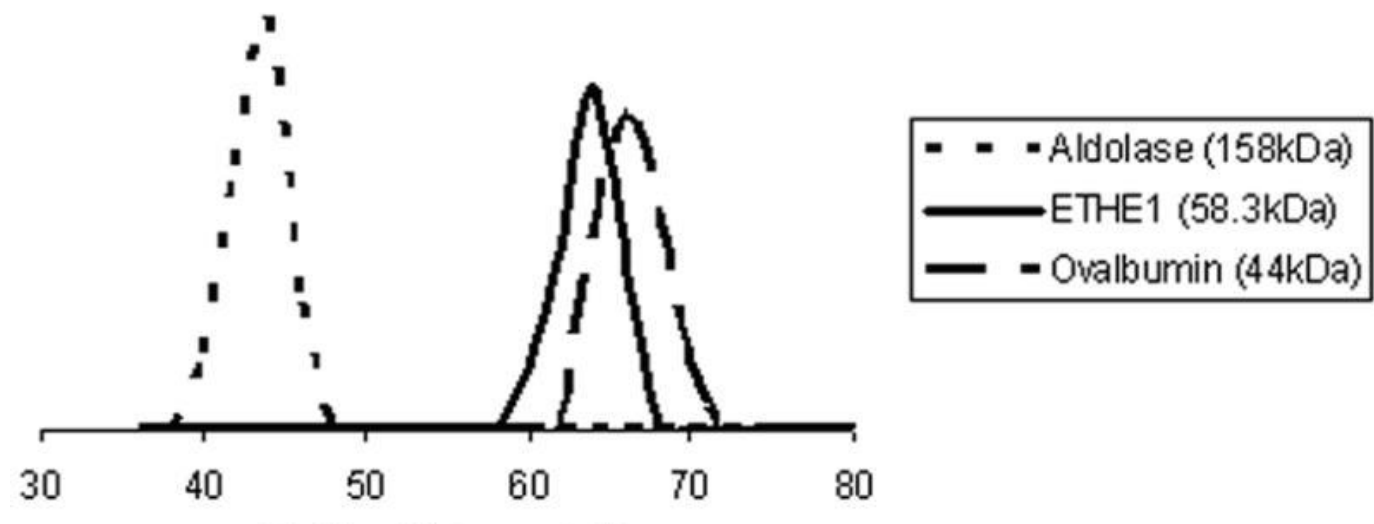

Elution Volume (ml)

Figure 2: Gel filtration elution profile of internal protein standards and ETHE1 Approximately $1 \mathrm{mg}$ of each of the following internal protein standards was separated on a Sephacryl S200 column: blue dextran, bovine serum albumin, ovalbumin, aldolase, and ribonuclease A. Protein containing fractions were monitored by $A_{280}$ as well as by SDS-PAGE.

\section{Metal Analyses}

GLX2 enzymes have been shown to bind iron, zinc, and manganese; therefore, ETHE1 was analyzed for all three of these metals and also copper $[\underline{11}, \underline{23}]$. The preparation of ETHE1 in rich medium containing no added metal ions resulted in an isolated enzyme that bound 0.2 equivalents of iron and no other metal ions at levels detectable with ICP-AES. When grown and over-expressed in rich medium containing $250 \mu \mathrm{M} \mathrm{Fe}\left(\mathrm{NH}_{4}\right)_{2}\left(\mathrm{SO}_{4}\right)_{2}$ and $\mathrm{Zn}\left(\mathrm{SO}_{4}\right)_{2}$ or $250 \mu \mathrm{M}$ $\mathrm{MnCl}_{2}$, ETHE1 was found to contain $0.33 \pm 0.10$ equivalents of iron and less than 0.003 equivalents of zinc, manganese, and copper. While low, this result suggested that ETHE1 may preferentially bind iron. The purified enzyme was incubated with a 4-molar excess of $\mathrm{Fe}$ (II) and dialyzed extensively ( $4 \mathrm{X} 1 \mathrm{~L}$ for four hours each) to remove loosely- or unbound $\mathrm{Fe}$, and ETHE1 was found to bind $1.2 \pm 0.2$ equivalents of iron, and no detectable traces of zinc, manganese, or copper. This result is consistent with the crystal structure [12], which showed that when prepared this way, ETHE1 only binds 1 equivalent of iron. Unlike the GLX2 enzymes, the addition of excess zinc or manganese to the 
isolated enzyme resulted in no additional metal binding, suggesting that ETHE1 may be specific for iron.

\section{ETHE1 Does Not Hydrolyze SLG}

ETHE1 had previously been predicted to be a GLX2-like enzyme [10]. However, ETHE1 is lacking several highly-conserved amino acids known to participate in the hydrogen bonding of SLG in GLX2 [12, 13]. Furthermore, crystallographic analysis showed that the substrate binding pocket of ETHE1 is too small to accommodate SLG [12]. These results suggested that Arabidopsis ETHE1 does not utilize SLG as a substrate. ETHE1, both as-isolated and after incubation with excess iron, was assayed for thioesterase activity with SLG and various other thioester derivatives of glutathione to test this hypothesis. Consistent our prediction, purified ETHE1 did not hydrolyze any of the glutathione thioesters.

As-isolated ETHE1 and Fe-enriched ETHE1 were also assayed against 188 different substrates, including 95 substrates for peptidases, 17 substrates for diverse reactions, and 76 substrates for glycolytic enzymes, phosphatases, and esterases using a commercially-available substrate screening plate []ㅡ to investigate potential substrates. Three potential substrates were identified through this screening process: Ala-Ala-Ala-p-nitroanilide (NA), Glu-pNA, and $p$-nitrophenyl acetate (NPA). Upon further characterization, Ala-AlaAla-pNA and Glu-pNA were found not to be substrates for ETHE1. However, ETHE1 did exhibit a low level of activity against $p$-NPA (2.02 $\pm 0.46 \mathrm{nmols} / \mathrm{min} / \mathrm{mg}$ of enzyme). This low level of activity is similar to the esterase activity $(25.8 \mathrm{nmols} / \mathrm{min} / \mathrm{mg}$ ) observed in recombinant rat carbonic anhydrase III when reacted with $p$-nitrophenyl acetate [24]. The activity of ETHE1 towards $p$-nitrophenyl acetate was inhibited by the presence of a metal chelator, 1,10-o-phenanthroline, indicating that $p$-nitrophenyl acetate hydrolysis by ETHE1 requires bound metal. Therefore, based on these results and those of the crystal structure, we predict that the ETHE1 substrate may be a relatively small ester.

Journal of Inorganic Biochemistry, Vol. 102, No. 9 (September 2008): pg. 1825-1830. DOI. This article is (C Elsevier and permission has been granted for this version to appear in e-Publications@Marquette. Elsevier does not grant permission for this article to be further copied/distributed or hosted elsewhere without the express permission from Elsevier. 


\section{Spectroscopic Studies on ETHE1}

The metal binding site of iron-bound ETHE1 was investigated using ${ }^{1} \mathrm{H}$ NMR spectroscopy (Figure 3 ). The spectrum revealed the presence of 3 paramagnetically-shifted, down field resonances between 200 and $20 \mathrm{ppm}$ and no observable up field resonances > $-30 \mathrm{ppm}$. In this spectrum peaks $a$ and $c$ integrate to 1 proton each, while peak $b$ integrates to $2-3$ protons (Figure 3 ). Spectra were obtained at $7^{\circ} \mathrm{C}$ and $35^{\circ} \mathrm{C}$, and while all three peaks shifted up field with increasing temperature, peak $b$ did not split into 2 or more peaks, suggesting that this peak is due to at least 2 chemically-equivalent protons. To further investigate the identity of these protons, an NMR spectrum of ETHE1 in $80-90 \% \mathrm{D}_{2} \mathrm{O}$ was obtained (Figure 3). Peaks a and $c$ broadened slightly but still integrate to 1 proton each. The intensity of peak $b$ decreased by $85 \%$. Based on the resonance positions and line widths, peak $b$ can be assigned to two $\mathrm{N}-\mathrm{H}$ protons on histidines bound to $\mathrm{Fe}$ (II) or possibly to an antiferromagneticallycoupled Fe(III)Fe(II) center [ $\underline{25}, \underline{26}]$. The ETHE1 crystal structure shows that both of the histidine ligands are bound through the $\varepsilon$ nitrogen, and therefore, peaks $a$ and $c$ are likely due to the $\beta-\mathrm{CH}_{2}$ protons on the bound Asp ligand (Figure 3). We cannot rule out the possibility that these peaks are due to ortho protons on metal bound histidines, but these peaks are usually too broad to detect [27]. The NMR data were surprising, since we initially predicted that ETHE1 would have a metal binding site similar to those in the GLX2 family. NMR spectra from GLX2-5, which can contain a dinuclear iron center, shows at least eight paramagnetically-shifted resonances in between 110 and $-30 \mathrm{ppm}$ that correspond to protons on ligands bound to a $\mathrm{Fe}(\mathrm{III}) \mathrm{Fe}(\mathrm{II})$ antiferromagnetically-coupled center [11]. The recent crystal structure of ETHE1 demonstrated that His74 (His56 in GLX2-5) may not be in a position to coordinate a bound metal ion [12], which is consistent with NMR spectrum of ETHE1.

Journal of Inorganic Biochemistry, Vol. 102, No. 9 (September 2008): pg. 1825-1830. DOI. This article is @ Elsevier and permission has been granted for this version to appear in e-Publications@Marquette. Elsevier does not grant permission for this article to be further copied/distributed or hosted elsewhere without the express permission from Elsevier. 


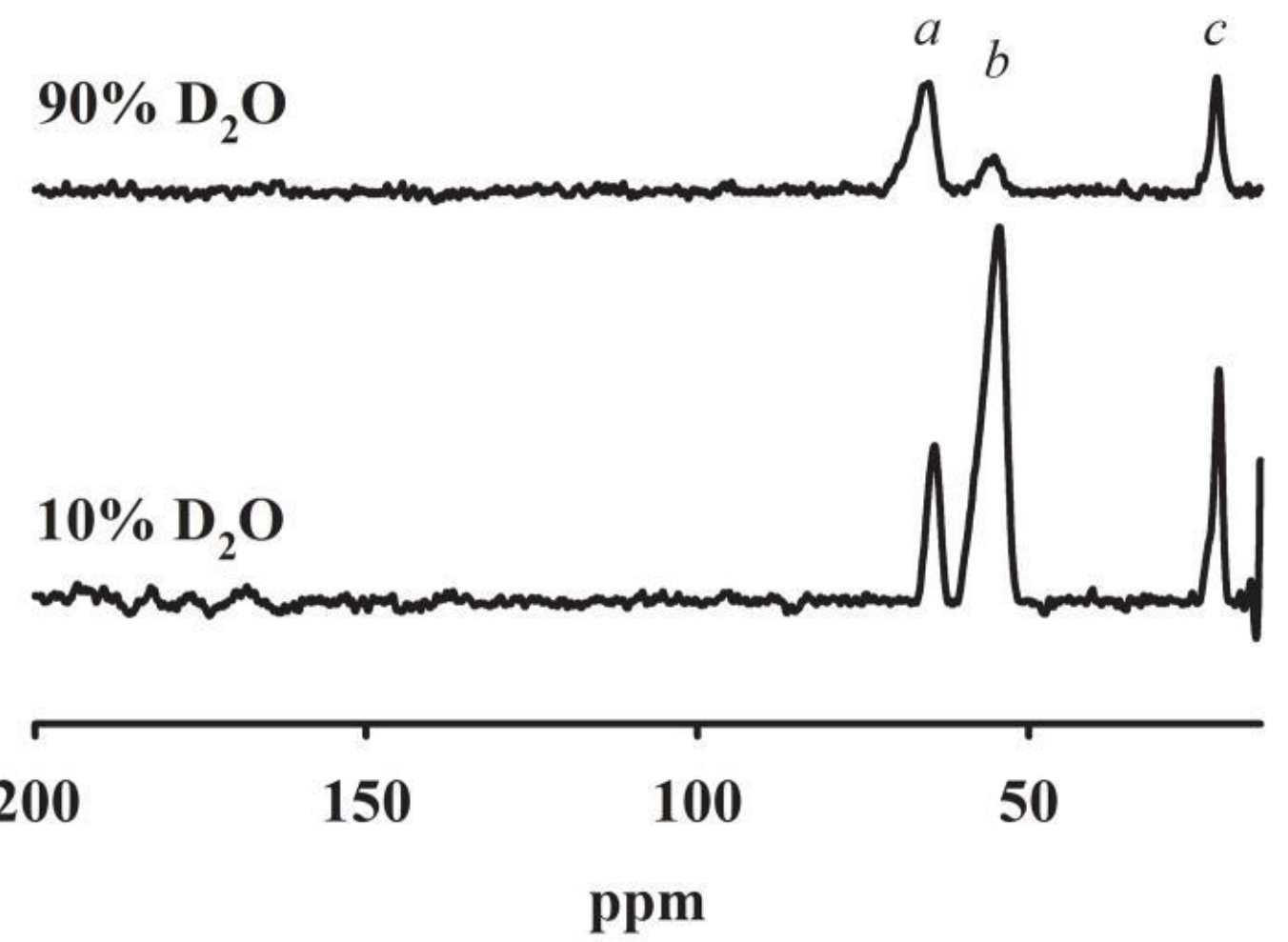

Figure 3: ${ }^{1} \mathrm{H}$ NMR spectra of $1.4 \mathrm{mM}$ iron-bound ETHE1 at pH 7.2 in water and 80-90\% $D_{2} O$

The spectra were obtained on a Bruker Avance 500 spectrometer operating at 500.13 $\mathrm{MHz}, 298 \mathrm{~K}$, and a magnetic field of 11.7 tesla, recycle delay (AQ), $41 \mathrm{~ms}$; sweep width, $400 \mathrm{ppm}$.

EPR spectra on several different forms of ETHE1 were obtained to further investigate the ETHE1 metal center. The spectrum of as-

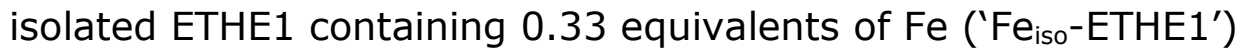
indicated the presence of rhombic Fe(III) (Figure 4). The signal was dominated by a broad derivative feature at $g_{\text {eff }}=4.27$; no features that could be considered diagnostic for protein-bound Fe(III) were observed and the origin of the signal is, therefore, unclear. Although precise quantitation of high-spin systems for which more than one Kramers' doublet is populated is not trivial, double integration and comparison with a similar EPR signal due to Fe(III) from a wellcharacterized (4-hydroxyphenyl) pyruvate dioxygenase [21] indicated an Fe(III) content of about $0.025 \mathrm{mM}$. Therefore about $95 \%$ of the iron in $\mathrm{Fe}_{\text {iso }}-\mathrm{ETHE1}$ is EPR-silent.

Journal of Inorganic Biochemistry, Vol. 102, No. 9 (September 2008): pg. 1825-1830. DOI. This article is @ Elsevier and permission has been granted for this version to appear in e-Publications@Marquette. Elsevier does not grant permission for this article to be further copied/distributed or hosted elsewhere without the express permission from Elsevier. 

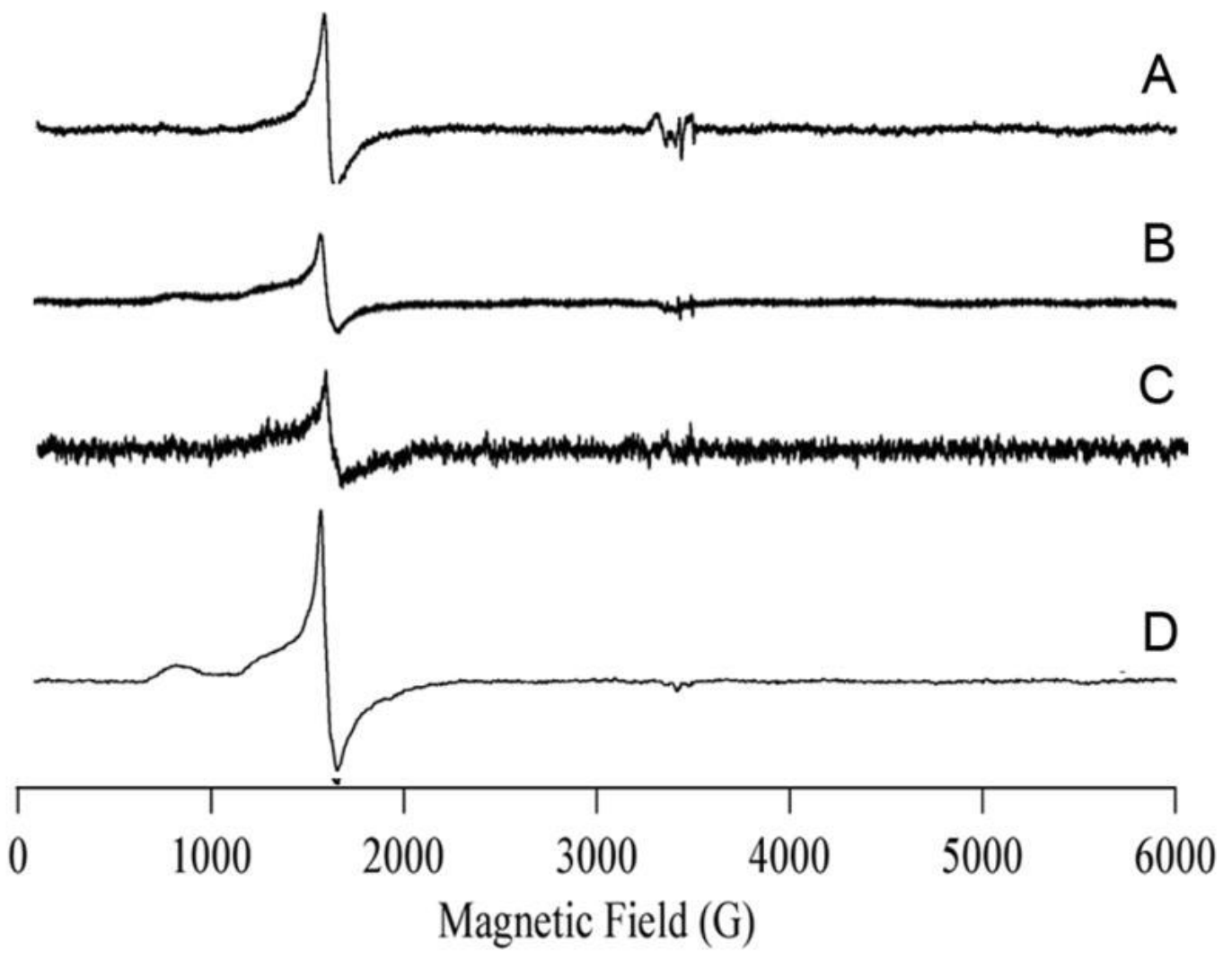

Figure 4: EPR spectram of $1.6 \mathrm{mM}$ ETHE1 under different conditions $\mathrm{A}, \mathrm{ETHE} 1$ as-isolated containing 0.33 equivalents of $\mathrm{Fe}$; $\mathrm{B}$, iron-enriched ETHE1 containing 1.2 equivalents of Fe; C, iron-enriched ETHE1 after 2 cycles of freeze/thaw; D, iron-enriched ETHE1 after 4 days at $4^{\circ} \mathrm{C}$. Spectra were collected on a Bruker ESP-300E spectrometer containing an ESR-900 helium flow cryostat operating at $4.7 \mathrm{~K}$ with 2 milliwatts of microwave power at 9.48 $\mathrm{GHz}$ and $10 \mathrm{G}$-field modulation at $100 \mathrm{kHz}$.

An Fe(III) signal with a resonance at $g \sim 4.3$ and additional absorption features at lower field were observed from the analysis of ETHE1 enzyme containing 1 equivalent of $\mathrm{Fe}$ (Fe $\mathrm{F}_{1}$-ETHE1) (Figure 4B). In this spectrum, the resonance positions indicated a dominant zerofield splitting term (i.e., $D, E \gg g \beta B S$; the lower field resonances centered at $g \sim 5.5$ and $g \sim 9$ terminate abruptly at $g=6$ and $g=10$, respectively); the lack of resolved structure and the broad absorption from $g \sim 4.3$ to $g \sim 10$ indicate a fairly broad distribution of the rhombic zero-field splitting parameter (i.e., strains in $E / D$ ) and thermal population of at least two Kramers' doublets [22]. Again, the signal was not definitive for site-specific binding of Fe(III) by ETHE1, although the form of the signal, particularly the inflection on the $g \sim$ 4.3 crossover due to incomplete rhombicity (i.e., $E / D$ is slightly less

Journal of Inorganic Biochemistry, Vol. 102, No. 9 (September 2008): pg. 1825-1830. DOI. This article is @ Elsevier and permission has been granted for this version to appear in e-Publications@Marquette. Elsevier does not grant permission for this article to be further copied/distributed or hosted elsewhere without the express permission from Elsevier. 
than $1 / 3$ ), is highly reminiscent of the spectrum due to $\mathrm{Fe}$ (III) bound to the active site of the metallo- $\beta$-lactamase GOB [26]. The intensity of the signal was somewhat lower than that of the as-isolated ETHE1 and accounted for $<1 \%$ of the total iron. Interestingly, there was no evidence for a ' $g \sim 1.7,1.8,1.9$ ' signal due to an Fe(II)-Fe(III) center [28].

We attempted to disrupt the protein structure of Fe $e_{1}$-ETHE1 by applying freeze-thaw cycles, but the EPR signal remained relatively constant (Figure 4C; fewer scans were averaged). Efforts to produce more $\mathrm{Fe}$ (III) in the sample by addition of hydrogen peroxide resulted in rapid protein precipitation. The intensity of the Fe(III) signal was found to increase by a factor of 4 upon aerobic incubation for $100 \mathrm{~h}$ at $4^{\circ} \mathrm{C}$ (Figure 4D). The form of this spectrum is clearly distinct from that of $\mathrm{Fe}_{\text {iso }}-\mathrm{ETHE} 1$, but still accounts for $<5 \%$ of the total Fe. Because of a weak background signal due to trace $\mathrm{Mn}$ (II) and $\mathrm{Cu}(\mathrm{II})$, the possibility of the presence of a signal due to an Fe(II)-Fe(III) center cannot be ruled out completely, but the population of such a center, if not zero, must be very low.

\section{Discussion}

Results presented in this work represent the first detailed characterization of an ETHE1 protein from any organism. ETHE1 is most similar to the GLX2-family of proteins, which are members of the metallo- $\beta$-lactamase superfamily. This superfamily consists of proteins that catalyze a wide range of reactions but share the common metal binding motif $\mathrm{H}-\mathrm{x}-[\mathrm{EH}]-\mathrm{X}-\mathrm{D}-[\mathrm{CRSH}]-\mathrm{X} 50-70-[\mathrm{CSD}]-\mathrm{X}$, which is part of the common $\beta$-lactamase fold [29]. This motif typically consists of two metal ions that are essential for the activity of the majority of the enzymes [29]. In most $\beta$-lactamase fold containing proteins, the coordination of the first metal $\left(Z n_{1}\right.$ site) is tetrahedral and consists of three histidines and a bridging hydroxide, while the second metal binding site $\left(Z n_{2}\right.$ site) is trigonal pyramidal. The site 2 metal binding ligands are more variable but always contain a histidine and aspartic acid (Figure 5A) [29]. Because of the similarity of ETHE1 to the GLX2 family of enzymes, it was predicted that ETHE1 would also bind two equivalents of metal. Metal analyses of ETHE1 done prior to this paper were based on a calculated extinction coefficient of $10,240 \mathrm{M}^{-1} \mathrm{~cm}^{-1}$ 
[12]. Metal analyses using this extinction coefficient indicated that iron-bound ETHE1 contained two equivalents of iron; however, the ETHE1 crystal structure reported only a 0.5 iron metal occupancy [12]. It was originally thought that this discrepancy resulted from the loss of metal during the crystallization processes [12]. However, results presented here suggest that the extinction coefficient used for these experiments is inaccurate. When using amino acid analyses, an extinction coefficient of $7,240 \mathrm{M}^{-1} \mathrm{~cm}^{-1}$ was obtained, which leads to a metal: protein stoichiometry of $1.2 \pm 0.2$. This number is consistent with the ETHE1 crystal structure [12].
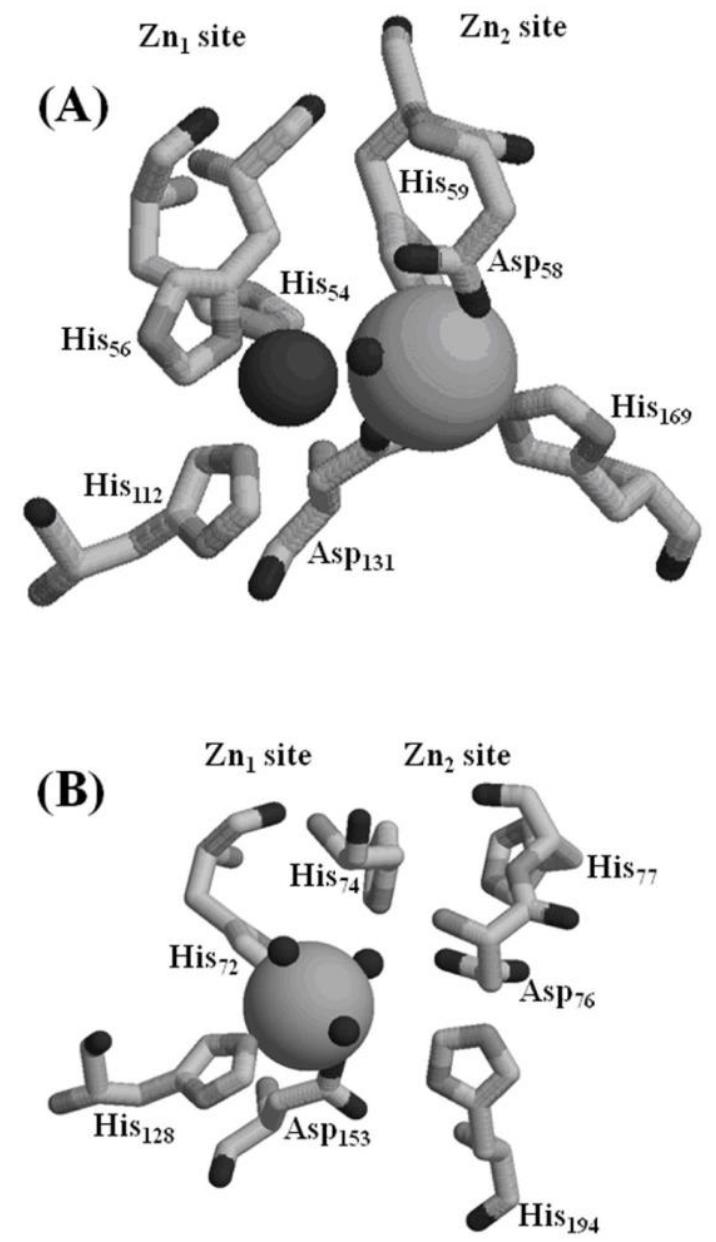

Figure 5: Metal binding sites of (A) A. thaliana GLX2-5 and (B) A. thaliana ETHE1. In GLX2-5, Zn(II) is coordinated by His54, His56, His112, Asp131, and a bridging hydroxide, and Fe(III) is coordinated by Asp58, His59, His169, Asp131, and the bridging hydroxide. In ETHE1, Fe(II) is coordinated by His72, His128, Asp153, and three solvent molecules. 
The crystal used to solve the structure of ETHE1 took several months to grow, and we were concerned that the resulting structure was due to an analog of the protein that was not biologically-relevant. However, consistent with the crystal structure of ETHE1, our spectroscopic results suggest that ETHE1 contains a single Fe(II) that is coordinated by two histidines (Figure 3) [12]. GLX2 enzymes enriched in iron typically contain an antiferromagnically-coupled $\mathrm{Fe}(\mathrm{II})-\mathrm{Fe}(\mathrm{III})$ center in their dinuclear metal binding site $[\underline{11}, \underline{23}, \underline{30}]$, due to the positive cooperative metal binding of these proteins. Results from our EPR studies argue against the presence of an Fe(II)$\mathrm{Fe}$ (III) site in ETHE1. Two distinct EPR signals were observed for ETHE1, both due to magnetically-isolated $\mathrm{Fe}$ (III) and both accounting for only a very small proportion ( $1-5 \%$ ) of the total iron. Even extensive exposure to air was unsuccessful in increasing the $\mathrm{Fe}$ (III) signal. The very low intensities of the Fe(III) signals can either be due to most of the iron being in the Fe(II) state or most of the iron residing in an anti-ferromagnetically-coupled $S^{\prime}=0$ dinuclear site. The lack of signals due to an Fe(III)-Fe(II) center and the crystallographic identification of a monometallated active site [12] both argue against a predominant $\mathrm{Fe}$ (III)-Fe(III) $S^{\prime}=0$ species and support $\mathrm{Fe}$ (II) as the predominant oxidation state of the metal in ETHE1.

Even though ETHE1 contains all of the highly-conserved metal binding ligands of the metallo- $\beta$-lactamase family of proteins [19], ETHE1 does not bind two equivalents of metal. In agreement with this result, the crystal structure identified changes in the tertiary structure of the metal binding domain that do not allow for the coordination of a second metal atom (Figure 5B) [12]. Based on the amino acid sequence comparison, we anticipated that the $Z \mathrm{n}_{1}$ site in ETHE1 would be made up of His72, His74, His128, and Asp153, while the $\mathrm{Zn}_{2}$ site would have Asp76, His77, Asp153, and His194. In ETHE1, Fe binds to 3 of the 4 ligands in the $Z n_{1}$ site (His72, His128, and Asp153). A single-turn helix in ETHE1 containing His74 is pulled away from the active site, displacing His74 $4.4 \AA$ away from the metal atom in ETHE1 relative to GLX2-5. This unwinding of the helix also displaces the side chains of Asp76 and His77, and the comparable amino acids in GLX2-5 (Asp58 and His59) bind metal in the $\mathrm{Zn}_{2}$ site (Figure 5) [12]. Therefore, subtle changes in protein conformation have displaced several of the metal binding ligands, ultimately limiting the ability of ETHE1 to bind two metal ions.

Journal of Inorganic Biochemistry, Vol. 102, No. 9 (September 2008): pg. 1825-1830. DOI. This article is (C Elsevier and permission has been granted for this version to appear in e-Publications@Marquette. Elsevier does not grant permission for this article to be further copied/distributed or hosted elsewhere without the express permission from Elsevier. 
NOT THE PUBLISHED VERSION; this is the author's final, peer-reviewed manuscript. The published version may be accessed by following the link in the citation at the bottom of the page.

There are other examples of metallo- $\beta$-lactamases that only bind one metal. CphA from Aeromonas hydrophila and GOB-1 from Elizabethkinga meningosptica both only bind a single $\mathrm{Zn}$ (II) atom in the $Z \mathrm{n}_{2}$ site (Asp, Cys, His) [31, 32]. However, in these enzymes, the $\mathrm{Zn}_{1}$ site is altered either by the replacement of a histidine with an

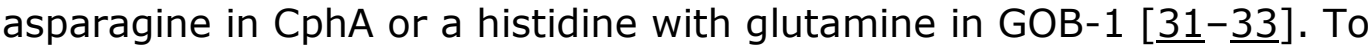
our knowledge ETHE1 is the first example of a $\beta$-lactamase family protein that contains all of the conserved metal-binding ligands, yet only binds one metal ion.

In addition, it has been shown that the presence of soft or hard ligands in the metal binding site can affect the specificity of the metal binding [29]. All of the metallo- $\beta$-lactamases exclusively bind $\mathrm{Zn}$ (II) [29]. The incorporation of an aspartic acid and an additional histidine in the $\mathrm{Zn}_{2}$ site likely allows for the variable binding of $\mathrm{Fe}, \mathrm{Zn}$, and $\mathrm{Mn}$ seen in the GLX2 enzymes (Figure 5A) [픈 11, 13, 30]. Likewise, the replacement of two soft ligands by an aspartic acid and a glutamate as observed in ROO allows the formation of a di-iron center $[\underline{9}, \underline{29}]$. Interestingly, in the ETHE1 crystal structure, the Fe ion is bound in the $\mathrm{Zn}_{1}$ site that has been modified by the removal of a histidine and the shifting the GLX2 bridging aspartic acid to specifically coordinate the iron (Figure 5B) [12]. The Fe(II) ion is further coordinated by three water molecules resulting in an octahedrally-bound metal $[\underline{12}, \underline{34}]$, unlike the tetrahedral coordination of metal normally seen in the $Z n_{1}$ site of metallo- $\beta$-lactamases.

Therefore, ETHE1 proteins appear to represent a new class in the metallo- $\beta$-lactamase fold family of proteins. Although structurally very similar to the GLX2 enzymes, ETHE1 appears to have evolved to bind a single iron atom in an octahedral configuration. Metal analyses and spectroscopic data suggest that unlike GLX2 enzymes ETHE1 tightly binds to a single $\mathrm{Fe}(\mathrm{II})$ atom in a modified $Z \mathrm{n}_{1}$ site of the metallo- $\beta$-lactamase metal binding motif. Finally we show that ETHE1 is homodimeric in solution and exhibits low levels of esterase activity, suggesting that ETHE1 might hydrolyze a short-chain ester. The metal binding site in ETHE1, with 2 His, 1 Asp, and 3 water molecules (Figure $\underline{5 B})$, resemble the 2-His-1-carboxylate facial triad, which has been reported in a number of $\mathrm{O}_{2}$-utilizing reactions $[\underline{35}, \underline{36}]$. However, ETHE1 does not share similar tertiary structural or amino acid sequence motifs with any of the enzymes known to have the 2-His-1-

Journal of Inorganic Biochemistry, Vol. 102, No. 9 (September 2008): pg. 1825-1830. DOI. This article is (C Elsevier and permission has been granted for this version to appear in e-Publications@Marquette. Elsevier does not grant permission for this article to be further copied/distributed or hosted elsewhere without the express permission from Elsevier. 
carboxylate facial triad. In addition, a ${ }^{1} \mathrm{H}$ NMR spectrum on a sample of ETHE1 containing a-ketoglutarate showed no change in the resonance positions of the paramagnetically-shifted protons, suggesting that ETHE1 is not an a-ketoglutarate-dependent enzyme (data not shown). Further experiments are required to further classify the ETHE1 substrate and ultimately understand its biochemical role.

\section{Acknowledgments}

This work was supported by the National Institutes of Health (EB001980, AI056231 to B.B., GM40052 to M.W.C.), the National Science Foundation (MCB-9817083 to C.A.M.) and the Ohio Plant Biotechnology Consortium (to C.A.M.). The authors thank Sriram Devanathan and Zhenxin Hu for obtaining some of the ${ }^{1} \mathrm{H}$ NMR spectra.

Publisher's Disclaimer: This is a PDF file of an unedited manuscript that has been accepted for publication. As a service to our customers we are providing this early version of the manuscript. The manuscript will undergo copyediting, typesetting, and review of the resulting proof before it is published in its final citable form. Please note that during the production process errors may be discovered which could affect the content, and all legal disclaimers that apply to the journal pertain.

\section{References}

1. Tiranti V, D'Adamo P, Briem E, Ferrari G, Mineri R, Lamantea E, Mandel H, Balestri P, Garcia-Silva MT, Vollmer B, Rinaldo P, Hahn SH, Leonard J, Rahman S, Dionisi-Vici C, Garavagilia B, Gasparini P, Zeviani M. Am J Hum Genet. 2004;74:239-252.

2. Tiranti V, Briem E, Lamantea E, Mineri R, Papaleo E, Gioia LD, Forlani F, Rinaldo P, Dickson P, Abu-Libdeh B, Cindro-Heberle L, Owaidha M, Jack RM, Christensen E, Burlina A, Zeviani M. J Med Genet. 2006;43:340-346.

3. Burlina A, Zacchello F, Dionisi-Vici C, Bertini E, Sabetta G, Bennet MJ, Hale DE, Schmidt-Sommerfield E, Rinaldo P. Lancet. 1991;338:1522-1523.

4. Thornalley P. Mol Aspects Medicine. 1993;14:287-371.

5. Aravind L. In Silico Biol. 1999;1:69-91.

6. Crowder MW, Spencer J, Vila AJ. Acc Chem Res. 2006;39:721-728.

7. Zang TM, Hollman DA, Crawford PA, Crowder MW, Makaroff CA. J Biol Chem. 2001;276:4788-4795.

8. Vogel A, Borchers T, Marcus K, Meyer HE, Krebs B, Spener F. Arch Biochem Biophys. 2002;401:164-172.

Journal of Inorganic Biochemistry, Vol. 102, No. 9 (September 2008): pg. 1825-1830. DOI. This article is (C Elsevier and permission has been granted for this version to appear in e-Publications@Marquette. Elsevier does not grant permission for this article to be further copied/distributed or hosted elsewhere without the express permission from Elsevier. 
9. Frazao C, Silva G, Gomes CM, Matias P, Coelho R, Sieker L, Macedo S, Liu MY, Oliveira S, Teixeira M, Xavier AV, Rodrigues-Pousada C, Carrondo MA, Le Gall J. Nature Struct Biol. 2000;7:1041-1045.

10. Maiti MK, Krishnasamy S, Owen HA, Makaroff CA. Plant Mol Biol. $1997 ; 35: 471-481$.

11. Marasinghe GPK, Sander IM, Bennett B, Periyannan G, Yang KW, Makaroff CA, Crowder MW. J Biol Chem. 2005;280:40668-40675.

12. McCoy JG, Bingman CA, Bitto E, Holdorf MM, Makaroff CA, Phillips GNJ. Acta Crystallogr D Biol Crystallogr. 2006;62:964-970.

13. Cameron AD, Ridderstrom M, Olin B, Mannervik B. Structure. 1999; 7:1067-1078.

14. Uotila L. Methods Enzymol. 1981;77:424-430.

15. Anderson RA, Bosron WF, Kennedy FS, Vallee BL. Proc Natl Acad Sci. $1975 ; 72: 2989-2993$.

16. Brandt JJ, Chatwood LL, Yang KW, Crowder MW. Anal Biochem. 1999;272:94-99.

17. Armstrong JM, Myers DV, Verpoorte JA, Edsall JT. J Biol Chem. $1966 ; 241: 5137-5149$.

18. Sabastian JF, Lo WY. Can J Biochem. 1978;56:329-333.

19. Crowder MW, Wang Z, Franklin SL, Zovinka EP, Benkovic SJ. Biochemistry. 1996;35:12126-12132.

20. Cooper RA. In: Method Enzymol. Abelson JN, Simon MI, editors. Academic Press; New York: 1975. pp. 502-508.

21. Purpero VM, Moran GR. Biochemistry. 2006;45:6044-6055.

22. Copik AJ, Waterson S, Swierczek SI, Bennett B, Holz RC. Inorg Chem. 2005;44:1160-1162.

23. Schilling O, Wenzel N, Naylor M, Vogel A, Crowder M, Makaroff C, MeyerKlaucke W. Biochemistry. 2003;42:11777-11786.

24. Kim G, Selengut J, Levine RL. Arch Biochem Biophys. 2000;377:334-340.

25. Bertini I, Turano P, Vila AJ. Chem Rev. 1993;93:2833-2932.

26. Moran-Barrio J, Gonzalez JM, Lisa MN, Costello AL, Peraro MD, Carloni P, Bennett B, Tierney DL, Limansky AS, Viale AM, Vila AJ. J Biol Chem. 2007;282:18286-18293.

27. Wang Z, Ming MJ, Que L, Vincent JB, Crowder MW, Averill BA. Biochemistry. 1992;31:5263-5268.

28. Crowder MW, Vincent JB, Averill BA. Biochemistry. 1992;31:9603-9608.

29. Gomes CM, Frazao C, Xavier AV, Legall J, Teixeira M. Protein Sci. 2002; 11:707-712.

30. Wenzel NF, Carenbauer AL, Pfiester MP, Schilling O, Meyer-Klaucke W, Makaroff CA, Crowder MW. J Biol Inorg Chem. 2004;9:429-438.

31. Garau G, Bebrone C, Anne C, Galleni M, Frere JM, Dideberg O. J Mol Biol. $2005 ; 345: 785-795$.

Journal of Inorganic Biochemistry, Vol. 102, No. 9 (September 2008): pg. 1825-1830. DOI. This article is (C Elsevier and permission has been granted for this version to appear in e-Publications@Marquette. Elsevier does not grant permission for this article to be further copied/distributed or hosted elsewhere without the express permission from Elsevier. 
NOT THE PUBLISHED VERSION; this is the author's final, peer-reviewed manuscript. The published version may be accessed by following the link in the citation at the bottom of the page.

32. Bellais S, Poirel L, Leotard S, Naas T, Nordmann P. Antimicro Agents Chemo. 2000;44:3028-3034.

33. Vanhove M, Zakhem M, Devreese B, Franceschini N, Anne C, Bebrone C, Amicosante G, Rossolini GM, Van Beeumen J, Frere JM, Galleni M. Cell Mol Life Sci. 2003;60:2501-2509.

34. Gomes CM, Silva G, Oliveira S, LeGall J, Liu MY, Xavier AV, RodriguesPousada C, Teixeira MJ. J Biol Chem. 1997;272:22502-22508.

35. Koehntop KD, Emerson JP, Que L. J Biol Inorg Chem. 2005;10:87-93.

36. Hegg EL, Que L. Eur J Biochem. 1997;250:625-629.

Corresponding authors. Tel.: +1 513529 7274; fax: +1 5135295715

(M.W. Crowder); tel.: +1 513529 2813; fax: +1 5135295715 (C.A.

Makaroff).

E-mail addresses: crowdemw@muohio.edu (M.W. Crowder), makaroca@muohio.edu (C.A. Makaroff). 